\title{
Higher Education System: Key Subjects of Educational Policy
}

\section{Sistema de educación superior: temas clave de la política educativa}

\author{
Tatyana N. Vasyagina \\ vasyagina_mai@mail.ru \\ https://orcid.org/0000-0003-2781-3741 \\ https://www.scopus.com/authid/detail.uri?authorld=57212301545 \\ $\mathrm{PhD}$ in Social Sciences, Associate Professor, Moscow Aviation Institute \\ (National Research University), Moscow, Russia. \\ Natalya V. Osipova \\ osipova.n.mai@mail.ru \\ https://orcid.org/0000-0002-9795-4534 \\ https://www.scopus.com/authid/detail.uri?authorld=57212301545 \\ $\mathrm{PhD}$ in Social Sciences, Associate Professor, Moscow Aviation Institute \\ (National Research University), Moscow, Russia.
}

Recibido: 02/05/21

Aceptado: 08/06/21

\begin{abstract}
The article is devoted to the key subjects of educational policy, on which the quality of the educational sphere depends. One of these subjects is teachers of higher educational institutions as a special social group, which has a leading role in shaping the intellectual, professional and scientific potential of society. A lot of research is devoted to the problems of teachers, but the issues of their self-identification remain relevant and, at the same time, insufficiently studied. The capacity of narrow professionals to solve the complex tasks of social life is insufficient. Another key subject of educational policy is the state as a guarantor of quality higher education. In most European countries, the state, due to historical traditions and resources, remains the main guarantor of the national education system. In the article, on the basis of our own sociological studies conducted in one of Moscow universities among teachers and students, as well as a secondary analysis of sociological research data conducted in a number of regions and universities of the country, some problems were identified that prevent the creation of an effective management model in the field of education.
\end{abstract}

Keywords: development; higher education system; identity; intelligentsia; resources; soft power; key actors; teachers; students; self-identification. 


\section{Resumen}

El artículo está dedicado a los temas clave de la política educativa, de los que depende la calidad del ámbito educativo. Una de estas asignaturas son los docentes de las instituciones de educación superior como grupo social especial, que tiene un papel protagónico en la conformación del potencial intelectual, profesional y científico de la sociedad. Se dedica mucha investigación a los problemas de los profesores, pero las cuestiones de su autoidentificación siguen siendo relevantes y, al mismo tiempo, insuficientemente estudiadas. La capacidad de los profesionales estrechos para resolver las complejas tareas de la vida social es insuficiente. Otro tema clave de la política educativa es el Estado como garante de una educación superior de calidad. En la mayoría de los países europeos, el Estado, debido a las tradiciones y los recursos históricos, sigue siendo el principal garante del sistema educativo nacional. En el artículo, sobre la base de nuestros propios estudios sociológicos realizados en una de las universidades de Moscú entre profesores y estudiantes, así como un análisis secundario de datos de investigación sociológica realizados en varias regiones y universidades del país, se identificaron algunos problemas que Impedir la creación de un modelo de gestión eficaz en el ámbito de la educación.

Keywords: desarrollo; sistema de educación superior; identidad; intelectualidad; recursos; Poder suave; actores clave; maestros estudiantes; autoidentificación.

\section{Introduction}

Society has a serious demand for quality higher education, as sociological studies show. Motivation for this education remained high ratings in youth consciousness at the beginning of the 21 st century, despite the life difficulties. At the same time, dissatisfaction with higher education in the country among various social groups and sectors of society, according to researchers, is widespread (Seryakova \& Krasinskaya, 2013; Krasinskaya, 2015; Hagurov \& Ostapenko, 2015).

According to regional studies in 2016-2017, the pace of modernization of higher education and the radical nature of approaches have not been adequately perceived by the main institutional entities, primarily the teaching community, students and university bureaucracy (Zborovsky et al., 2017).

Relations within the university community, between the main institutional subjects (teachers, students and heads) are controversial. These relations are determined by strict regulation, formalization and corporate secrecy. Such relations do not allow the university to function as a holistic system (Zborovsky et al., 2017).

The topic relevance is due to the destruction threat of the higher education system in the transition to new educational technologies, coupled with the danger of promoting applied technologies for managing mass consciousness. Object of study are teachers, students 
and heads as a factor in the replenishment and increment of intellectual potential. The subject of the study is the behavior of key subjects of educational policy and their impact on the educational strategy. The purpose of the study is to identify the dependence of the educational strategy on the self-identification of key actors, primarily the teaching community, students and university bureaucracy; elimination of negative trends in higher education, taking into account the self-identification of key subjects of educational policy. The main tasks arising from the study goal:

- to consider restarting the higher education system, taking into account Russian characteristics;

- to identify the importance of key subjects of educational policy;

- to study the transition features from the governance paternalistic model to the model of mutual and joint responsibility of society and the state;

- to study the attitude of teachers and students towards educational policy.

The important way to obtain sociological information were our own sociological research, held at a Moscow university among teachers and students, secondary analysis of sociological research data conducted in a number of regions and universities of the country, published literature analysis, periodicals, statistical data, personal observations and other open sources.

The work implements sociocultural, systemic approach, including methods of sociological, institutional and comparative historical analysis.

When analyzing the institute of higher education in modern Russia, most authors pay attention to the unpreparedness of the reform of higher education, haste dictated by departmental interests and lack of thought in borrowing, which could not guarantee a positive result.

The sociological tradition in the study of modern problems of higher education is actively developed by the following researchers: G. E. Zborovsky, P. A. Ambarova and E. A. Shuklina (Zborovsky et al., 2017), which comprehend relations within the university community between the main institutional actors, primarily teachers and students. The behavior of university employees under the reform of higher education is studied by $M$. V. Kurbatova, E. S. Kagan and N.F. Aparina (Kurbatova et al., 2015).

Russian researchers note the importance of the social institution of higher education in the imperial, Soviet and modern periods. The interdisciplinary and systematic approach to education, which in the general form consists in studying educational problems in a sociocultural and historical context, is implemented on the pages of the scientific journals "Sociological Studies" (Kalmykov \& Satyr, 2016), "Higher Education in Russia" (Andreev, 2009; Andreev, 2017; Nikolsky, 2009; Gorokhov, 2010; Senashenko \& Makarova, 2018; Ivakhnenko, 2018), «Sociology of Education» (Hagurov \& Ostapenko, 2015), «Social and Humanitarian Knowledge» (Pusko, 2013), etc. 
Discussions about higher education continue for many years on the pages of regional magazines "Kazan Social and Humanitarian Bulletin" (Zelenaya \& Utkina, 2016; Minzaripov et al., 2019), collective monographs (Danilchenko \& Razdina, 2009; Danilchenko, 2018; Kozlovsky, 1997; Shemeneva, 2017), in the framework of international and scientific conferences (Gromyko, 2019; Magaril, 2019; Chavkina, 2019; Shkarubo, 2018), as well as in periodicals.

Many studies are devoted to the social well-being, content of work and material problems of university teachers (Toshchenko, 2012; Krasinskaya, 2015; Minzaripov et al., 2019).

The authors reveal the reasons for teachers' dissatisfaction with educational policies: such as dissatisfaction with university bureaucracy, academic overload, social inequality, low salaries, over-exploitation and formalization of indicators (Minzaripov et al., 2019).

The studies of A. Yu. Andreev (2009); V. S. Gavrilov, V. I. Kolesnikov, E. V. Olesyuk and A. A. Shulus (2009); V. S. Nikolsky (2009); V. G. Gorokhov (2010); (S. B. Seryakova and L. F. Krasinskaya, (2013); T. A. Hagurov and A. A. Ostapenko, (2015); N. I. Kalmykov and T. S. Satyr (2016); A. L. Andreev (2017), V. S. Senashenko and A. A. Makarova (2018) are of the great interest for understanding the modern problems of higher education and the prospects for its development.

In these works, negative managerial influences on the educational system are actively investigated, which lead to inconsistencies, imbalance in the higher education system and loss of stability. It is revealed that the main type of management in the system of higher education is pressure "from above" and subjective bureaucracy. According to E. N. Ivakhnenko (Ivakhnenko, 2018), external mechanical managerial influence on the educational system in some cases does not bring the expected effect, and in others it destroys previous achievements.

There is a low level of trust among university teachers in the administration of their university and in the reform policy. The level of trust of students in the educational policy of the university and the educational strategy of the Russian Federation in relation to higher education is even lower (Zborovsky et al., 2017).

The purpose of structural renaming and merging of faculties, when former faculties are called "institutes" or "schools" is to neutralize objectionable leaders, namely deans and head of department, which cease to be elected at the competitive basis and which previously could not be fired (Chuykov, 2019).

However, the issues of self-identification of university professors remain relevant and at the same time insufficiently studied. Most of the university professors and scientists referred to the intelligentsia in Soviet times (Toshchenko, 2001). 
According to K. Manheim (Manheim, 2000) the expression "educated" allows getting the first idea of the phenomenon of intelligency. "Being educated" means something like being involved in a situation that affects everyone. C. Manheim describes the intelligentsia as an open stratum.

"A huge intellectual proletariat" is what the ideologist of the Vichy government in France Ch. Maurras calls the intelligentsia, who has the fate of which continue wearing "the tatters of what used to be our literature and our art" (Maurras, 2003). The consequences of the erroneous policy of the state in educational strategy in the context of globalization are investigated by the English scientist G. Standing. He introduced the concept of "precariate" into scientific circulation as a new dangerous class (Standing, 2014).

Tough bureaucratic regulation, regulation of university life gives rise to institutional conflicts, problem of management efficiency and undermines the trust of the university community in higher education policies implemented by the authorities. Many people see the meaning of changes in the educational system in activating the processes of selfdevelopment, strengthening initiatives "from below", at the level of the university and social partners through the formation of horizontal connections (Zborovsky et al., 2017).

The vector of educational policy can be aimed at imitation and simulation of educational and research activities, that is, at the destruction of the higher education system and at ensuring the joint responsibility of all participants in the educational space. From bureaucratic subjectivity and self-government, it is necessary to move to university autonomy and self-government.

The social state burdens financial capital with costly social responsibility, therefore it is criticized by the financial oligarchy, hence the attack on the rights of citizens, projects leading to the degradation of education due to the infringement of the creative sphere associated with science, "with full the connivance of consumer hedonism" at the top of society (Panarin, 2003).

The state functions consist in coordinating the interests of key subjects of the educational field and observing the principle of social responsibility in relation to education, one of the main areas of society that determine the quality of the people life. The state must regain the people confidence, which was lost in the nineties. Cooperation between the state and the society is impossible without the confidence of the people in the state.

\section{Methodology}

The article contains a comparative historical analysis, methodological foundations, interpretation of the results, both of their own sociological surveys conducted by the team of the laboratory of scientific foundations of education at Moscow State Aviation Technological University (Hegel \& Osipova, 2006; Bolotin, 2002), and secondary analysis of all-Russian and regional studies. The results of the research are compared with the results of similar research in recent years. 
The surveys were conducted during 1998-1999, 1999-2000, 2000-2001 and 2002-2003. with the assistance of MATI students. The sample consisted of 452,811 and 893 students and teachers. The research concept, program and tools, as well as computer processing of data arrays using the SPSS Statistics program was carried out under the guidance of Doctor of Sociological Sciences, Professor L.A. Hegel (Hegel \& Osipova, 2006; Bolotin, 2002; Hegel \& Vasyagina, 2003).

Comparative historical analysis shows that the Russian higher education system, conservative in its core, has European origins. The significant influence on its creation had a German university tradition at the initial stage, and the achievements of the French engineering education system were borrowed at the beginning of the 19th century (Senashenko \& Makarova, 2018).

The state in tsarist Russia strove to be the guarantor of a high educational standard, which ensured the well-known stability (conservatism) of higher education. This made it possible to maintain traditional values on the one hand (the law of God was taught in higher educational institutions), and to master new areas of knowledge on the other hand. In the XVIII century, Russia borrowed rationalism, ideas of the Enlightenment, liberal ideas, and then Marxism in the West, which became important factors in the further development of civilization.

Higher school of Russia developed very dynamically by the beginning of the XX century. As of January 1, 1917, the country had 65 state universities belonging to different departments, including 28 universities equated to them. At the same time, there were 41 public institutes and 17 private universities (Zmeev, 1998).

However, it was not possible to grow the necessary mass of the intellectual elite, whose moral qualities would have allowed to avoid a national catastrophe during the First World War and subsequent revolutionary upheavals, since the majority of the Russian population (peasantry) was deprived of the efforts of the ruling class elementary education, and therefore was deprived of subjectivity, that is, the ability to participate in the transformation of Russia. After the fall of the Russian Empire, the Philosophical Steamboat took many famous representatives of the educated class from the country.

In the study of the modern higher school in Russia, the results of sociological surveys of students and teachers of one of Moscow aviation universities - MATI named after K. E. Tsiolkovsky. The Student and the Teacher Questionnaire were developed. The survey was conducted in Moscow in May 2002. The research concept, program and tools, as well as computer processing of formation arrays under the Statistical Package for the Social Sciences program was carried out under the guidance of, Doctor of Sociology, Professor L. A. Hegel (Hegel \& Vasyagina, 2003; Hegel et al., 2008).

In some cases, the data of surveys of students and teachers of MATI were compared with the data obtained at the Russian State University for the Humanities and Center for 
Tatyana N. Vasyagina, Natalya V. Osipova.

Sociological Research of Moscow State University, as well as in one of the Moscow institutes in 2013, where a study of the value-motivational aspects of the activities of teachers was conducted under the guidance of the academician of the Russian Academy of Natural Sciences S. L. Danilchenko (Ulyanova, 2017).

According to regional surveys of 2016-2017 the level of trust of teachers and students of universities of the Ural Federal District to the administration of their university and to the educational policy of the Russian Federation in relation to higher education was studied, the total number of universities of the Ural Federal District was 51 (Zborovsky et al., 2017).

Russia's accession to the Bologna process was supposed to contribute to the inclusion of Russian education in the international educational space, to advance the higher education system towards the European liberal educational model, however, the reform did not give the desired results, so the return to the Soviet educational model was soon outlined (Senashenko \& Makarova, 2018).

The technocratic approach widely used today began to gain strength against this backdrop, which sees the way out in the digitalization of the university environment, in the creation of online courses, etc (Danilchenko, 2018).

Priority is given to the artificial intelligence (AI) creation, the technocracy leadership associated with IT technologies, the "chipization" of the entire population. The question arises: will it be possible to preserve the biosocial nature of man? Humanities warn about danger of creating stricter social control than in a totalitarian society. They insist that the priority is not robotization, but development and education in Russia of wide, highly intellectual class of nationally responsible intelligentsia (Magaril, 2019; Bolotin, 2002; Hegel et al., 2008; Levicheva, 2001; Magaril, 2001).

Much depends on whose strategy prevails. The sociocultural approach connects civilizational and class approaches into a single whole, figuring out a combination of stable structures (anthropological, ethnic and cultural), variable structure (social and personal) and others (Lapin, 2000).

\section{Results}

Russian Education Separation as a Social System and its Restart: to the Question Fate of the Mass Intelligentsia

Russian higher education system has traditionally been one of the best in the world, although secular higher education institutions have appeared several centuries later in comparison with Europe in Russia. The higher education history in Russia began with the Slavic-Greek-Latin Academy, the first higher educational institution founded in 1687, created on the initiative of Simeon Polotskiy after his death. M.V. Lomonosov studied at the Academy. The next stage is the period of Peter I, when the triad "Academy - University 
๔eduweb

Revista de Tecnología de Información y Comunicación en Educación • Volumen 15, Nㅜ 2. Mayo-agosto 2021

- Gymnasium" was imported from Prussia to the new Russian capital, St. Petersburg in the first quarter of the 18th century (Shkarubo, 2018).

An example for the developing domestic higher education system has been German institutions since the founding of the Academy in Saint Petersburg in 1725 and the first Moscow University in 1755. However, there are many distinguishing features in the charters of Russian and German universities with similar goals and structures. European education trends have also affected Russian higher education. However, Catherine II considered harmful the knowledge spread among the people, which she openly wrote in a letter to Count Saltykov (Shkarubo, 2018; Magaril, 2019).

The following system of educational institutions was adopted in the 18th century: parishional schools, county schools, gymnasiums and universities. It was emphasized that "Parishional schools should exist primarily for peasants, bourgeois and lower-class industrialists; county schools should exist for merchants, chief officers' children and nobles; gymnasium should be mainly for noblemen" (Bulkin, 2001).

The first university charter appeared in 1804 under Alexander I, and the Ministry of Education appeared for the first time, whose role is quite eloquent, given that less than $10 \%$ of the population was literate by the time of the serfdom abolition (Pushkarev, 2008).

The 1804 charter for the first time granted autonomy to Russian universities: the election of rector and professors, its own court, the non-interference of the administration in the university affairs, etc. Since 1819, the gymnasiums was paid, which prevented the entry of children of "ignoble" conditions into them, the nobility sought to further protect children from the "harmful mix", and "noble institutions" were opened in the provinces. In 1864, there were already 51 of them (Kinelev, 1995).

Thus, the educational system was launched at the turn of the 18th-19th centuries, which found its own borders, its own internal organization and cyclicality despite the influence of other national systems, mainly German. There was a separation of the education system from other social systems. The education signs as a system are educational institutions, ministerial and regional governance structures, and layers of officials, teachers, students and gymnasium students (Ivakhnenko, 2018).

The question of measures to limit access to high schools and universities for youth from taxation estates was repeatedly discussed under Nicholas I in the 1940s. The oldest technical higher education institutions in Russia arose at the same time during this period: Moscow Vocational School (MVTU named N. E. Bauman) and Saint Petersburg Technology Institute. A graduate of a technical university, an engineer, was a prominent figure in prerevolutionary Russia (Senashenko \& Makarova, 2018).

Universities were the education system core and were designed to ensure its effectiveness. Persons of all classes could enter the university formally, but higher 
education did not extend to peasants in reality. This has led to a dramatic split over time: a high European level of higher and secondary education for the privileged and propertied sections of the population on the one hand and a lack of a sufficient number of schools for the people on the other hand (Bulkin, 2001).

Thus, the majority of the Russian population by the efforts of the ruling class was deprived of basic education and therefore was deprived of subjectivity, that is, the ability to participate in the transformation of Russia. The bourgeois reforms of the 1860s in the field of education, which were carried out by the liberal bureaucracy, were no exception.

The new university charter of 1863 was adopted first, which returned the autonomy selected by Nicholas I to the universities. However, students did not receive the right to self-government, which led to the increase in tension between the government and the students, and the strengthening of revolutionary radicalism among students. The counterreform of Alexander III restored the estate principle in higher education, and the new charter of 1864 deprived the universities of autonomy. It was impossible now to enter universities without a police certificate of trustworthiness. All student organizations were banned, tuition doubled. Higher courses for women were closed for several years. The "Circular about cook's children" was adopted in 1887 to prevent children from the "lower classes" from entering universities (Medynsky, 1929).

The share of the nobility in the composition of students of educational institutions of the XIX century, under the jurisdiction of the Ministry of Public Education, amounted to half of all students. For comparison: in the 1914-1915 academic year, there were 32.4\% children of noblemen and officials studied in nine Russian universities, honorary citizens and merchants $-11.5 \%$, clergy $-7.6 \%$, philistines - $24.6 \%$, peasants and Cossacks $14.6 \%$, others $-4.4 \%$ (Kinelev, 1995).

The state contributed to the development of higher education by funding laboratories, classrooms, observatories, and scientific societies. Public opinion also turned to science, making the scientist an almost iconic figure. The success confirmation of Russian science and education by the beginning of the 20th century is the fact that Russia ranked fifth in the world in terms of the number of scientists, scientific journals, publications, universities and discoveries, second only to Germany, the USA, England and France (Ivakhnenko, 2018).

There were thirteen literate people for each of the hundred recruits in Russia on the other hand, in 1916, and eighty five were in Germany. About three quarters of the adult people in Russia could neither read nor write on the eve of October, 1917 (Kozlovsky, 1997).

Many famous representatives of the educated class left the country after the Russian Empire fall. Recognition abroad received aircraft designer I.I. Sikorsky, "father of television" V.K. Zvorykin, director of the United States National Radio Astronomy Observatory O.L. Struve, professor at Harvard University P.A. Sorokin and others (Shlykova, 2017; Shkarubo, 2017). 
๔eduweb

Revista de Tecnología de Información y Comunicación en Educación • Volumen 15, Nㅜ 2. Mayo-agosto 2021

The events of October 1917 split the intelligentsia into two hostile camps. Bolsheviks were opposed by both individual representatives of the intelligentsia and its public organizations (Shlykova, 2017).

However, the Bolsheviks managed to mobilize scientific knowledge and the mass education system in the framework of their project, despite all the difficulties. Soviet society rejected not only the practice of elitism, but its idea. Particularly noticeable are the transformations of the 1930s, when there was a need for industrialization. Sectoral institutes were created for the development of industry in a short time, which ensured the mass graduation of engineers (Senashenko \& Makarova, 2018). About 60 million people became literate during the cultural revolution by 1940 , and millions of qualified engineers were trained by 1960 (Magaril, 2019).

The education system was restarted in the society with its own cycles and ways of interacting with the government and society along with other radical changes (Ivakhnenko, 2018). Former empire from a peripheral player in the world economy system has turned into a space superpower, which set the world a high social bar.

We have the opposite picture after the USSR collapse. A significant part of the resources leaves the country. Russia again has an economy built into the world system of labor division as a supplier of raw materials. This was preceded by the socalled "crisis of values" in the late USSR. There was another restart of the national educational system. How did he affect the mass intelligentsia?

In 2002, 33\% of MATI students, based on the material wealth of their family and living conditions, considered themselves to be "lower middle", and $22 \%$ - to the "higher middle" layer. The rest were distributed as follows: $28 \%$ - found it difficult to answer, $3 \%$ attributed themselves to the "upper" layer, 6\% - to the "lower higher", 7\% - to the "higher lower" and $1 \%$ - to the "lower" layer.

Students 'self-esteem was higher than the teachers' opinion of them, that is, young people had a better opinion of themselves, although they were quite self-critical. $83 \%$ of students had a positive opinion about MATI students. But most of them admitted that they "medium" rate "responsibility" (59\%) and "morality" (53\%) of MATI students. 62\% "medium" rated "hard work", only $24 \%$ thought that they were studying "at full strength".

With intensive work, the material level of teachers' families remained rather low. The meager salary in the 1990s led many to the path of social degradation. According to the results of studies conducted in Moscow at the Russian State University for the Humanities, at the beginning of the XX century, $81 \%$ of teachers valued their profession, but two thirds of them believed that in society it was assessed as not promising. More than $80 \%$ worked in other places, and it was the main source of income (Levicheva, 2001). 
Tatyana N. Vasyagina, Natalya V. Osipova.

A significant part of the respondents, teachers of MATI, had a positive, although sometimes rather contradictory, attitude to the profession and higher education. 95\%, that is, the overwhelming number of teachers, answered that they value their profession, but one in five $(20 \%)$ thought that his profession in society was rated as "not important and not promising", $75 \%$ - "as necessary but not promising".

A distinctive feature of this subject is the heterogeneity and ability to respond to "external challenges", based on the capabilities of its internal resource. The intelligentsia, demonstrating the will and considerable potential, relies mainly on itself, but depending on historical traditions and resources it depends on the state.

If the people's intelligentsia as a subject does not find in themselves an internal motivation for action, and delegates its subjectivity to an external regulator that initiates transformations, then it risks losing not only the people's trust, but also its borders as a self-developing organism, and can disappear forever, dissolving into "Precariate" according to forecasts of G. Standing (Standing, 2014).

The social inequality of various layers of Russian society is growing, which inevitably implies an increase in the activity of social forces interested in various scenarios of social development. The decisive role is played by the ability of social actors to respond to the "challenges" of the time, to restrain unwanted and dangerous trends and to promote desirable processes.

Self-Identification of Key Institutional Subjects of the Educational Policy of Modern Russia

The Institute of Nomenclature, which was destroyed during the Yeltsin era, began to be restored from 1995, which led to the return of the principle of gradual advancement in the career ladder in the 2000s. There are almost no cases of a "big leap" in a career. In modern Russia, the Soviet mechanism of bureaucratic promotion of the best personnel is broken, and the new one has not yet formed and does not fully work. Therefore, climbing to elite places is not regulated either by the state or by society. Often such an ascent has a "thieves" or criminal character. At the same time, new social groups emerging in Russian society begin to advance their cadres (Bolotin, 2002).

Today, most researchers understand the subjects of educational policy: state, regional and municipal governments, federal and regional institutions, national educational community that is aware of its problems and resources, administration of educational bodies, parents, family, teachers and students, scientific, cultural and social institutions, departments, mass media, professional, pedagogical communities, each citizen individually and international body education, and world educational community. We can talk about the multipolarity of the subject of educational policy in this case (Kozubenko, 2017).

The multisubjective nature of the educational policy in the conditions of diversification of education (from the Latin diversificato - change, diversity) should not lead to shifting the 
responsibility of the state for the results of the educational process to other participants in the educational field: university community, family, parents, regional authorities, local governments or even business.

Today advocates of the technocratic development model have come to the fore in a liberal ideology crisis. The most fashionable trend in the Russian Federation is the creation of a digital economy and Al. At the head of the strategy is Sberbank. The government is ready to spend about 90 billion rubles on these goals. The task is to integrate the Russian Federation into the global governance system. Specialists, engineers and scientists will be engaged in applied tasks beyond the scope of these reforms (Losev, 2019).

Does the intelligentsia have the potential to preserve their identity, value structure, and avoid marginalization and deintellectualization or it will turn into a "precariat" (Standing, 2014)?

The success of higher education reform depends on the self-identification of key subjects of educational policy. The main institutional subjects should be aware of their civilizational values. Relations within the educational community can be divided into two poles. One characterizes the relationship between teachers and students and within the scientific and pedagogical community. The other characterizes the relationship between the leadership of the university and another one. Relations are built on the trust principles in the first case. They are determined by strict regulation, formalization and corporate closeness in the second case. Such relationships are not organic and do not allow the university to function as a holistic system системе (Zborovsky et al., 2017).

The modernization pace of higher education and the radical nature of approaches were not adequately perceived by the main institutional actors, primarily the teaching community, according to regional studies in $2016-2017$. Teachers $(76.8 \%)$ believe that the main type of governance in higher education is pressure "from above" and bureaucratization (Zborovsky et al., 2017).

The newly appointed directors of "schools" and "departments" are in a difficult situation of choice, which will receive more independence in decision-making and even some financial resources, but they can be dismissed by order. It is about building the notorious "power vertical". The purpose of structural renaming, merging of faculties, when former faculties are called "institutes" or "schools" and university chairs are called "departments", is to neutralize article 332 of the Labor Code of the Russian Federation, which makes deans and head of department elected on a competitive basis. The goal of renaming is to get rid of leaders who cannot be fired (Chuykov, 2019).

Tight state regulation gives rise to the institutional conflicts and the problem of management efficiency. This problem is identified when considering the phenomenon of institutional trust. For example, the trust level of university teachers in the Ural Federal District to the administration of their university is $47.1 \%$ and to the reform policy is $36.4 \%$. 
Tatyana N. Vasyagina, Natalya V. Osipova.

It is even lower the level of students' confidence in the educational policy of the university (34.8\%) and the educational policy of the Russian Federation in relation to higher education (27\%). The total population included 51 universities of the Ural Federal District (Zborovsky et al., 2017).

External mechanical managerial impact on the educational system in some cases does not bring the expected effect, it destroys previous achievements, leads to inconsistencies, imbalance in the higher education system, and loss of stability in others cases (Ivakhnenko, 2018). Dissatisfaction with higher education is widespread. This refers to assessments of various social groups and sectors of society (Seryakova \& Krasinskaya, 2013; Krasinskaya, 2015; Hagurov \& Ostapenko, 2015).

A study of the value-motivational aspects of the teachers' activities in one of the Moscow institutes in 2013 was conducted under the academician guidance of the Russian Academy of Natural Sciences S. Danilchenko. Respondents (986 people) are Moscow teachers from 28 to 76 years old. There was a tendency to increase the role of the material factor and to decrease in the internal motivation for creativity in the hierarchy of motivations for creative activity. Moreover, this trend was identified among young teachers. Creativity was not an independent value for them (Ulyanova, 2017).

We should not idealize the relation between teachers and students who put forward serious claims to each other. One of the reasons of this is the time lack for the former and the proper motivation lack for others. We can talk according to researchers about the formation of an opportunism strategy among some teachers under the conditions of a sharp increase in workload (Zborovsky et al., 2017).

The educational strategy vector must be directed from the willfulness of individual officials and departments to university self-government in these conditions, that is, the transformation of the university community from an object of manipulation into a collective subject and a customer of educational policy. Business as the main customer of professional personnel does not cope with its task. It is known that the labor market needs are quite opportunistic, and personality formation is a long-term process.

A significant subject of educational policy is parents and family. However, pension reform has increased the retirement age of grandparents. Is it possible under these conditions to shift the responsibility for the education and upbringing of children? An important subject of educational policy is university graduates from the "Generation Z". These are those who were born from the mid-1990s to 2010 (21.5 million of young people) according to training.ru. These are graduates of the Internet and Youtube (Shestak, 2018).

Computer technologies have both positive and negative consequences, they place high demands on the professional level of a specialist, can contribute to the growth of creativity and the degradation of thinking, and the threat of "digital autism" increases. The technocratic approach, which may prevail due to the enthusiasm of some managers for 
the idea of digitalizing the country, leads not only to the destruction of classical education, but also to another violent breaking of traditions.

\section{Discussion}

It is beneficial for the state to have an expensive egalitarian higher education, since the preparation of the country's nationally-oriented managerial elite depends on this. Highquality education cannot be cheap for the state, but it must be massive and accessible to the people as a subject of culture.

The mistakes of the governing bureaucracy in the field of education can lead not only to the disappearance of a sovereign nation-state, but also to the governing elite when transferring their functions to robotic corporations, owners of Big Data and new digital platforms.

In the XX century. The topic of higher education was actively developed by American scientists, among whom are A. Flexner and T. Veblen with his idea of creating a model of an autonomous higher educational institution of a research type and protest against the management of universities by business (Hegel \& Osipova, 2006; Veblen, 2011).

The task of the state is to pay attention to the key subjects of educational policy, on which the elimination of negative tendencies in higher education depends, ensuring the true self-identification of these subjects and their influence on public opinion. The total number of students in Russia studying in higher education programs is about 4.3 million people today, according to statistics. $90 \%$ of them study in state educational institutions of higher education. 3.03 million people study at the bachelor's program, 0.51 million people study at the master program, 0.7 million people study at the specialty and 0.09 million people study at the graduate school (Chavkina, 2019).

One of the goals in the field of education proclaims the development of cultural centers outside the territory of the state: the first English-language Russian channel "RussiaToday" was created, the project "Trendline's Russia" as an application to the world's leading newspapers. This is the "soft power" that attracts foreign students, the future elite, which contributes to the development of international relations and relations (Naumov, 2015).

The development of modern higher education as a social institution during the transition to a new technological order has under itself not only an objective basis, but also represents a subjective process that depends on key actors that have an impact on educational strategy. Underestimating this leads to the "brain drain" and the dispersal of civilizational intelligence.

Tight state regulation gives rise to institutional conflicts, the problem of institutional trust and management efficiency. The main type of management in the system of higher 
education is subjective bureaucracy and pressure "from above". Does Russia face a managerial impasse today and is a catastrophe brewing in the system of higher education? What is planned to be done to overcome the lag that, according to the assessment of the President of the Russian Academy of Sciences A. Sergeev, has reached a critical level (Chuykov, 2019)?

The former Soviet top bureaucracy, motivated by enrichment, tried to become a part of the Western elite after the collapse of the USSR. There were calls to "change civilization" instead of the official ideology. An external project is being implemented in Russia today as a result that no one has seen yet, but this does not mean that it does not exist, according to Vladimir Lepekhin, director of the Eurasian Economic Community (Lepekhin, 2014).

One of the areas of modern world cognitive warfare is the introduction of new educational standards and technologies, based on the complete transformation of the humanities: hence the forced introduction of the Unified State Exam, distance education, online testing, overexploitation of teachers and scientists. Therefore, Russia needs a key subject capable of upholding civilizational values.

The vector of the educational strategy must be directed from the willfulness of individual officials and departments to university self-government, that is, the transformation of the university community from an object of manipulation into a collective subject and customer of educational policy.

\section{Conclusions}

Strict bureaucratic regulation and formalization of university life leads not only to institutional conflicts, reduces management efficiency, undermines the trust of the university community in higher education policies implemented by the authorities, but also gives rise to the problem of self-identification key institutional actors of educational policy in the future. The relations within the university community, between the "tops" and "lower classes", do not allow the university to function as an integral system (Zborovsky et al., 2017).

The meaning of changes in the educational system is to intensify the processes of selfdevelopment, to strengthen initiatives "from below", at the level of the university and social partners. The vector of educational policy should not be aimed at imitating and simulating the results of educational and research activities, that is, not at the destruction of the higher education system, but at ensuring the joint responsibility of all participants in the educational space. From bureaucratic subjectivity and self-government it is necessary to move on to university autonomy and self-government.

The unpreparedness of higher education reform, the haste dictated by departmental interests, and the lack of thought in borrowing could not guarantee a positive result. However, the higher education system, rooted in the best European, Russian and Soviet 
traditions, turned out to be quite stable in the context of the next sociocultural crisis of the beginning of the 21st century. Further transformation of higher education will depend on whether the discussion of educational reform can be transferred from the departmental and corporate levels to the national one. The positions of various subjects of the educational field may clearly contradict each other and differ in mutually exclusive strategies. Therefore, innovations should be combined with traditions in the transition to a new technological structure.

Successful development of the national higher education system is impossible without a deep understanding of its fundamental sociocultural characteristics. Another restart of the updated educational system depends on the self-identification of key institutional actors. To create an updated educational system and an attractive image of the future, the country needs managerial personnel who identify with the people, are able to act, aware of their civilizational responsibility.

\section{References}

Andreev, A. L. (2017). Society and education: experience of pre-revolutionary Russia. Higher education in Russia, 11, 158-164.

Andreev, A. Yu. (2009). About the "new reading" of the history of Russian universities. Higher education in Russia, 3, 149-159.

Bolotin, I. S. (2002). Elite and intelligentsia in transforming Russia. Intellectuals and modernity. Issue 3. Moscow: Russian State University for the Humanities.

Bulkin, A. P. (2001). Sociocultural dynamics of education: historical experience of Russia. Dubna: Fenix+.

Chavkina, A. Sh. (2019). Socialization management of modern student youth. Scientificpractical conference "Youth of the XXI century: development vectors in the space of a new social reality", Moscow Aviation Institute (National Research University), 53-55.

Chuykov, A. (2019). Interview with President of the Russian Academy of Sciences A. Sergeev. Arguments of the Week, 36(680).

Danilchenko, S. L. (2018). Continuing education system development in Russia, Society, Science, Education: Trends and Prospects for Development: Collective Monograph. Ufa: AETERNA.

Danilchenko, S. L., \& Razdina, A. V. (2009). Organization of research activities of young scientists in Russia: History and modernity. Monograph. Moscow: Moscow State Pedagogical University.

Gavrilov, V. S., Kolesnikov, V. I., Olesyuk, E. V., \& Shulus, A. A. (2009). To the question of national models of education. Higher Education in Russia, 3, 137-149.

Gorokhov, V. G. (2010). Lessons from the reform of education in Russia at the end of the XIX - beginning of the XX centuries. Higher education in Russia, 5, 147-154.

Gromyko, Yu. V. (2019). Resuscitation of the Russian education system. Challenges and opportunities: Another coordinate system and navigator of a living subject of education. Moscow: Keldysh Institute of Applied Mathematics.

Hagurov, T. A., \& Ostapenko, A. A. (2015). Reforms of Russian education through the eyes of the professional community. Sociology of Education, 10, 43. 
Hegel, L. A., \& Osipova. N. V. (2006). Modern university as a social institution. Moscow: Moscow State Aviation Technological University.

Hegel, L. A., \& Vasyagina, T. N. (2003). Sociology of the intelligentsia. Moscow: MATI.

Hegel, L. A., Zubkov, V. I., \& Nikolaev, G. G. (2008). Value orientations of Russian students: socio-political and educational aspects. Moscow: Printing house "Paradise".

Ivakhnenko, E. N. (2018). Domestic education as a system and object of management. Higher education in Russia, 27(8), 9-23.

Kalmykov, N. N., \& Satyr, T. S. (2016). Russian higher education: view of experts. Sociological studies, 8, 91.

Kinelev, V. G. (1995) Higher education in Russia: an outline of history until 1917. Moscow: Research Institute of Higher Education.

Kozlovsky, P. (1997). Farewell to Marxism-Leninism: on the logic of the transition from developed socialism to ethical and democratic capitalism. Essays on Personalist Philosophy. St. Petersburg: Economic school.

Kozubenko, I. I. (2017). The multipolarity of understanding of the subject of educational policy, Modern Education: Theory and Practice: Collective Monograph. Ufa: AETERNA.

Krasinskaya, L. F. (2015). Higher school teacher: what should he be? (reflections on social expectations and professional realities). Higher education in Russia, 1, 37-46.

Kurbatova, M. V., Kagan, E. S., \& Aparina, N. F. (2015). Behavior of university workers in the context of reforming higher education: problem of choice. Sociological Studies, 2, 123134.

Lapin, N. I. (2000). Russia's Ways: Sociocultural Transformations. Moscow: Institute of Philosophy RAS.

Lepekhin, V. A. (2014). National idea found. Available at http://ria.ru/zinoviev_club/20140731/101812426.html

Levicheva, V. F. (2001). Humanitarian Intelligence: The Foundations of Corporate Identity. Case studies, 2, 57-61.

Losev, A. (2019). About the disappearance of the "oil needle" and magicians of the digital economy. Arguments of the Week, 40(684), 1-3.

Magaril, S. A. (2001). Civil responsibility of the intelligentsia. Sociological studies, 2, 51-57.

Magaril, S. A. (2019). Why does the public consciousness of Russia reject liberal ideas? Actual issues of state, municipal government and the economy: problems, technologies, innova-tions. Materials of the international scientific-practical conference, Moscow Aviation Institute (National Research University), 139-149.

Manheim, K. (2000). Selected: Sociology of Culture. Moscow: University Book.

Maurras, Ch. (2003). The Future of the Intelligentsia. Moscow: Praksis (Series "Ideolo-gies").

Medynsky, E. N. (1929). The history of pedagogy in connection with the economic development of society. Moscow: Education Worker.

Minzaripov, R. G., Fursova, V., \& Makhambetova, M. (2019). Material status of university teachers in the context of the problems of social well-being. Kazan Social and Humanitarian Bulletin, 5(40), 9-14.

Naumov, A. (2015). "Soft Power" and the foreign policy image of the Russian Federation. Prospects, Available at http://www.perspektivy.info/book/magkaja_sila_i_vneshnepoliticheskij_imidzh_rossijs koj_federacii_2015-03-30.htmB

Nikolsky, V. S. (2009). How can you not talk about the Russian model of the university. Higher education in Russia, 2, 126-131. 
Panarin, A. S. (2003). Strategic instability in the 21st century. Moscow: Algorithm. Pushkarev, B. S. (2008). Two "Russias" of the 20th century. 1917-1993. Moscow: Posev.

Pusko, V. S. (2013). Humanitarian component of engineering education. Social-humanitarian knowledge, 5, 108-116.

Senashenko, V. S., \& Makarova, A. A. (2018). Educational hybrids in higher education in Russia. Higher education in Russia, 27(8), 24-42.

Seryakova, S. B., \& Krasinskaya, L. F. (2013). Reform of higher education through the eyes of teachers 6 research results. Higher education in Russia, 11, 22-30.

Shemeneva, A. V. (2017). The system of higher education in France and Russia. Modern Education: Theory and Practice: Collective Monograph. Ufa: AETERNA.

Shestak, N. V. (2018). Lecture at a university in the context of a competency-based approach. Higher education in Russia, 27(8), 43-53.

Shkarubo, S. N. (2017). From the history of Russian scientific emigration to the United States in the 1920-1930. Our Fatherland, pages of history: Collection of scientific papers, issue 13. Moscow: Institute of Scientific and Technical Information.

Shkarubo, S. N. (2018). Gymnasium education in Russia: history and modernity. Ufa: AETERNA.

Shkarubo, S. N. (2018). Research activity of young scientists as an innovative resource of professional socialization. Socio-political and economic problems of modern Russia. Materi-als of the IV All-Russian Scientific and Practical Conference. Makhachkala: Dagestan State Pedagogical University.

Shlykova, L. A. (2017). October 1917 in the fate of the Russian intelligentsia. Our Fatherland, pages of history: Collection of scientific papers, issue 13. Moscow: Institute of Scien-tific and Technical Information.

Standing, G. (2014). Precariate: a new dangerous class. Moscow: Ad Marginem Press.

Toshchenko, Zh. T. (2001). Social status and image of the humanitarian intelligentsia. Series: Intellectual and Modern. Vol. 2. Moscow: Russian State University for the Humanities.

Toshchenko, Zh. T. (2012). New faces of activity: imitation. Sociological studies, 12, 23-36.

Ulyanova, M. V. (2017). Modernization processes in modern education: answers to the challenges of social realities. Modern Education: Theory and Practice: Collective Mono-graph. Ufa: AETERNA.

Veblen, T. (2011). The theore of the leisure class. Moscow: Book House "Librokom".

Zborovsky, G. E., Ambarova, P. A., \& Shuklina, E. A. (2017). Is there a higher education system in Russia? Sociological studies, 11, 76-86.

Zelenaya, L. G., \& Utkina, A. N. (2016). Diversification of regional universities and educational clusters. Kazan Social-Humanitarian Bulletin, 6, 42-47.

Zmeev, V. A. (1998). Evolution of higher education in the Russian Empire. Moscow: MATI. 